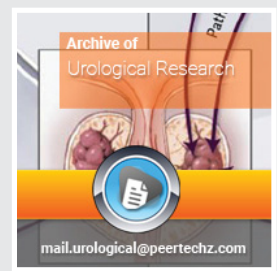

Clinical Group

\title{
Archive of Urological Research
}

Mateus Ferreira de Siqueira e Silva', Flávia Cristina Rodrigues de Sena', Ferdinando Agostinho ${ }^{2,3}$, Karlla Kristinna Almeida Medeiros ${ }^{4}$, Camila Botelho Miguel ${ }^{5,6}$ and Wellington Francisco Rodrigues ${ }^{6 *}$

'Faculdade Morgana Potrich - FAMP, Mineiros, GO, Brazil

2Pós-Graduação em Ciências Fisiológicas, Instituto de Ciências Biológicas e Naturais, Universidade Federal do Triângulo Mineiro - UFTM, Uberaba, MG, Brazil

${ }^{3}$ Faculdade de Fisioterapia, Universidade de Rio Verde - UniRV, Rio Verde, GO, Brazil

${ }^{4}$ Departamento de Nutrição e Alimentação Escolar, Secretaria municipal de Educação, Rio Verde, GO, Brazil

${ }^{5}$ Laboratório Morfofuncional, Centro Universitário de Mineiros - UNIFIMES, Mineiros, GO, Brazil

${ }^{6}$ Pós-Graduação em Ciências da Saúde, Universidade Federal do Triângulo Mineiro - UFTM, Uberaba, MG, Brazil

Received: 17 August, 2017

Accepted: 04 October, 2017

Published: 05 October, 2017

*Corresponding author: Wellington Francisco Rodrigues, Curso de Pós-graduação em Ciências da Saúde, Universidade Federal do Triângulo Mineiro, Uberaba, MG, Brazil, Tel: +55-34-370-06626; E-mail: wellington.frodrigues@hotmail.com

Keywords: Urinary tract infection; Escherichia coli; Bladder catheter

https://www.peertechz.com

\section{Introduction}

Hospital-acquired infections, also called nosocomial infections, are those that are acquired in a hospital environment, after discharge, or during hospital procedures [1].

There are several risk factors associated with infection during bladder catheterization delay, including colonization of the urethral meatus and the duration of catheterization. Colonization of the urethral meatus by potentially pathogenic bacteria was considered in a univariate analysis as the most important risk factor for bladder catheterization related bacteriuria [2].

In an intensive care unit, the most commonly found infections are urinary tract infections (UTI) or bacteriuria associated with the bladder catheter, pneumonia associated with mechanical ventilation, and bacteremia associated with the central venous catheter - all with very high morbidity and mortality [3,4].

Females are more susceptible to UTIs than males, with adult women 50 times more likely to acquire UTIs than men. Of these, $30 \%$ of women have symptomatic UTIs throughout their lives. The main route of urinary tract contamination is ascending; this is attributed to the short female urethra and the greater proximity between the vagina and the anus, characteristic of the female anatomy [5].

Although more common in women, the incidence of UTIs increases among men over 50 years of age [6]. Urinary tract instrumentation including bladder catheterization and the occurrence of prostatic disease are the factors most implicated in the increasing incidence of infection in males [4]. Among elderly and hospitalized individuals, UTI rates are elevated by the aforementioned factors as well as the presence of comorbidities that increase susceptibility to infections. UTI rates are much higher in male homosexuals, due to the practice of unprotected anal sex, in individuals with intact foreskin, and in HIV-infected patients [4].

Therefore, we believe that it is extremely important for health care professionals to understand the factors that influence the incidence of UTIs, with bladder catheterization 
being an major factor that predisposes this infection, so that we can take necessary actions to minimize its risks $[7,8]$. The present study hopes to contribute to the improvement of the quality of care provided to patients.

\section{Methods}

This study consisted of a review of the literature referring to the main publications that described the relationships between causes, risk factors, symptoms, diagnoses and treatments of UTIs.

The publication dates were from 1997 to 2016 and the accepted languages were Portuguese, English and Spanish. The researches were carried out in the electronic databases Medline, Pubmed, Scielo, Latin American and Caribbean Health Sciences Literature (LILACS). The terms used for the search are the following descriptors: infection, urinary tract, symptoms, diagnoses and treatments. Studies that related the descriptors, and presented relevance in the subject, as well as fit the period mentioned above were included in this study. The exclusion criteria were: Repeated articles in the databases consulted, and experimental studies without clinical application.

\section{Results}

After consulting the scientific articles on the different platforms, 25 studies were selected for evaluation and description. Among the variables listed in the articles are infection mechanism $(\mathrm{N}=6)$, prevention $(\mathrm{N}=3)$, treatment $(N=8)$, diagnosis $(N=3)$, and general approach $(N=7)$, where two articles evaluated more than one item, totaling 27 events related to the theme of this review. The treatment referral approach was highlighted with $29.63 \%$ of the studies, followed by description of general data $(25.93 \%)$, mechanisms of infection $(22.22 \%)$, prevention $(11.11 \%)$ and diagnosis $(11.11 \%)$ (Table 1).

\section{Discussion}

Our study allowed us to verify a high incidence of the number of studies related with hospital urinary infection, thus demonstrating an eminent concern with the number of individuals suffering from the disease, as well as the increase of infections linked to multiresistant microorganisms. UTIs are defined by the presence of a minimum of 100,000 bacterial $\mathrm{cfu} / \mathrm{mL}$ of urine [5]. Signs and symptoms associated with UTIs include polaciuria, urinary urgency, dysuria, change in the color and appearance of urine, accompanied by changes in urinary sediment, hematuria, and pyuria (>10,000 leukocytes/ $\mathrm{mL})$.

Table 1: Frequency of the variables related to urinary tract infection.

\begin{tabular}{|c|c|c|c|c|c|}
\hline & $\begin{array}{c}\text { Mechanism of } \\
\text { infection }\end{array}$ & Prevention & Treatment & Diagnosis & $\begin{array}{c}\text { General } \\
\text { approach }\end{array}$ \\
\hline $\begin{array}{c}\text { Absolute } \\
\text { values - N }\end{array}$ & 6.0 & 3.0 & 8.0 & 3.0 & 7.0 \\
\hline $\begin{array}{c}\text { Relative } \\
\text { values- \% }\end{array}$ & 22.22 & 11.11 & 29.63 & 11.11 & 25.93 \\
\hline
\end{tabular}

Total events
Abdominal pain is more common in the topography of the hypogastrium (projection of the bladder) and in the dorsum (projection of the kidneys), which may sometimes lead to fever [6]. UTIs can affect the lower urinary tract, known as cystitis, and the upper urinary tract, known as pyelonephritis. Lower UTI or cystitis may be symptomatic or asymptomatic [9].

Cystitis usually presents with dysuria, voiding urgency, polaciuria, nocturia, and suprapubic pain; however, fever is not a usual symptom. Pyelonephritis usually begins with cystitis and is often accompanied by high fever, usually $>38^{\circ} \mathrm{C}$, and is associated with chills and unilateral or bilateral lower back pain. Fever, chills, and lower back pain form the triad of symptoms characteristic of pyelonephritis, being present in most cases [4].

The etiological agents most commonly responsible for community-acquired UTIs are in order of frequency: Escherichia coli, Staphylococcus saprophyticus, Proteus and Klebsiella sp., and Enterococcus faecalis. E. coli alone accounts for $70 \%$ to $85 \%$ of community-acquired UTIs and $50 \%$ to $60 \%$ of elderly patients admitted to institutions [10].

When a UTI is acquired in an inpatient setting, the etiological agents are quite diverse, with enterobacteria predominating; with a reduction in the frequency of $E$. coli (although it remains the usual cause); and a growth of Proteus sp, Pseudomonas aeruginosa, Klebsiella sp., Enterobacter sp., Enterococcus faecalis, and fungi, especially Candida albicans $[11,12]$.

The term bacteriuria refers to the presence of bacteria in urine, without tissue invasion. In UTIs, tissue invasion by the above microorganisms causes local inflammation, which manifests signs and symptoms characteristic of this infection. The diagnosis of UTI is based on bacteriuria associated with signs and symptoms that indicate inflammation of the urinary tract [13].

The collection of urine for culture through urination should be performed after external genital cleansing. In catheterized patients, it is recommended to collect urine by puncturing the drainage system in the designated place, after thoroughly disinfecting $70 \%$ of the area with alcohol, keeping the system closed [13]

In a hospital, the diagnosis of UTI is complicated by several factors [14]. The presence of urinary catheters makes it difficult or impossible to verify the signs and symptoms associated with UTI. Dysuria, urinary urgency, or suprapubic discomfort may be related to the presence of a urinary catheter, regardless of the presence of UTI [15].

Most cases of UTI occur after bladder catheterization. Approximately $80 \%$ of hospital UTIs are associated with the use of a bladder catheter and $5 \%$ to $10 \%$ by other manipulations of the urinary tract. Approximately $10 \%$ of patients are catheterized during hospitalization for an average duration of 4 days. Between $10 \%$ and $20 \%$ of catheterized patients develop bacteriuria and $2 \%$ to $6 \%$ develop UTI symptoms. Urinary probing for more than 7 days is associated with UTI development in up to $25 \%$ of patients with a daily risk of $5 \%$ [13]. 
Complementary tests that may be useful for diagnosis are as follows: urine routine, uroculture, antibiogram, blood culture, and imaging (ultrasound, computed tomography, and magnetic resonance imaging).

The choice of antimicrobial therapy for UTI varies according to the presentation of the infection, host, and agent. Strategies involving different therapeutic regimens according to specific groups of patients maximize therapeutic benefits, in addition to reducing costs, incidence of adverse effects, and the emergence of resistant microorganisms [16].

Several studies have shown good sensitivity of gramnegative bacteria to ciprofloxacin and norfloxacin $[17,18,19]$. However, recent studies have shown a trend towards the development of microbial resistance to these drugs, highlighting factors such as empirical treatment, adherence to treatment, and costs [20]. For severe infections caused by Enterobacteriaceae, the use of gentamicin is recommended; this drug inhibits protein synthesis by blocking the formation of the initiation complex, binding to the bacterial ribosomal portion $30 \mathrm{~S}[21,22]$.

Linezolid is a promising drug for the treatment of infections with multiresistant gram-positive microorganisms. It is an oxazolidinone that inhibits protein synthesis by blocking formation of the initiation complex, binding to the bacterial ribosomal 50S portion [23]. Low levels of resistance were observed and may be associated with mutations in ribosomal RNA; however, it is suggested that susceptibility tests to this antimicrobial drug are performed before starting antibiotic therapy [24].

\section{Conclusion}

UTIs are responsible for high hospital infection rates. E. coli is the main etiological agent causing infections at home and in outpatients, whereas various other microorganisms cause infections in hospitalized patients.

Bladder catheterization delay is the main cause of UTIs in hospitalized patients, with an incidence of $80 \%$. As a consequence of the main agent generally being gram-negative, the drugs of choice are either ciprofloxacin and norfloxacin; for gram-positive cases, the drug of choice is linezoline. There are also various treatments against microbial susceptibility, given the large ratio of hospital resistances, including to the abovementioned drugs.

Infection is more frequent in women than in men due to the short female urethra and is directly related to bladder catheterization. From the moment the signs appear, the antibiotics of choice are indicated and a culture is performed to know the sensitivity profile of the agent.

However, the present study allows us to conclude that the hospital conditions are linked to more heterogeneous UTIs, the type of microorganism, as well as the treatment and forms of contagion. In addition, the quality of care provided to patients may reduce the number of hospital UTIs cases and result in shorter hospital stays.

\section{Acknowledgement}

The authors gratefully acknowledge the Pro-Rectory of Research and Graduate Studies of Federal University of Triangulo Mineiro, the Foundation for Research Support of the Minas Gerais State (FAPEMIG), and the Coordination of Improvement of Higher Level Personnel (CAPES), for the support and incentive to the development of researches.

\section{Financial support and sponsorship}

This work was supported by a Foundation for Research Support of the Minas Gerais State (FAPEMIG), and the Coordination of Improvement of Higher Level Personnel (CAPES). The funders had no role in study design, data collection and analysis, decision to publish, or preparation of the manuscript. WFR receives post-doctoral fellowship from National Postdoctoral Program of the Coordination for the Improvement of Higher Education Personnel (Social Demand/ PNPD/CAPES).

\section{References}

1. Brasil. Ministério da Saúde. Portaria $n^{\circ} 2616$, de 12 de maio de 1998. Aprova programa de controle de infecção hospitalar e das outras providências. Diário Oficial da República Federativa do Brasil, Brasília, 13 de maio 1998 Seção 1: 133-135.

2. Garibaldi RA, Burke JP, Britt MR, Miller MA, Smith CB (1980) Meatal colonization and catheter-associated bacteriuria. N Eng J Med 303: 316-318. Link: https://goo.gl/UpWiyk

3. David CMN (1998) Infecção em UTI. Medicina, Ribeirão Preto 31: 337-348. Link: https://goo.gl/CYVWk8

4. Lopes HV, Tavares W (2004) Projeto Diretrizes-Associação Médica Brasileira (AMB) e Conselho Federal de Medicina (CFM); Sociedade Brasileira de Infectologia e Sociedade Brasileira de Urologia. Infecções do Trato Urinário: Diagnóstico

5. Masson P, Matheson S, Webster AC, Craig JC (2009) Meta-analyses in prevention and treatment of urinary tract infections. Infect Dis Clin North Am 23: 355-385. Link: https://goo.gl/Q8pJpb

6. Head KA (2008) Natural approaches to prevention and treatment of infections of the lower urinary tract. Altern Med Rev 13: 227-244. Link: https://goo.gl/qCQUtK

7. Cyrino ACT, Stuchi RAG (2015) Infecção do trato urinário em um hospital de uma cidade no interior de minas gerais. Revista de Enfermagem ufjf 1: 39-44 Link: https://goo.gl/u3AK31

8. GIL, AC (2002) Como elaborar projetos de pesquisa. $4^{\mathrm{a}}$ ed. São Paulo: Atlas

9. Hooton TM, Stamm WE (1997) Diagnosis and treatment of uncomplicated urinary tract infection. Infect Dis Clin North Am 11: 551-581. Link: https://goo.gl/LcYM35

10. Rahn DD (2008) Urinary tract infections: contemporary management. Urol Nurs 28: 333-341. Link: https://goo.gl/WiL37r

11. Peleg AY, Hooper DC (2010) Hospital-acquired infections due to gramnegative bacteria. N Engl J Med 362: 1804-1813. Link: https://goo.gl/FFhQNY

12. Ksycki MF, Namias N (2009) Nosocomial urinary tract infection. Surg Clin North Am 475-481. Link: https://goo.gl/up95uc

13. Kuga APV, Fernandes MVL (2009) Prevention of Urinary Tract Infection (UTI) Related to Health Care - Paulista Association of Studies and Control of Hospital Infection - APECIH. 2nd edition. Sao Paulo 
14. Warren JW (2000) Nosocomial urinary tract infections. Gerald L. Mandell. In: Principles and Practice of infectious Diseases. 5th edition. Churchill Levingstone. Philadelphia 3028-3039.

15. Graves N, Tong E, Morton AP, Halton K, Curtis M, et al. 2007 Factors associated with health care-acquired urinary tract infection. Am $\mathrm{J}$ Infect Control 35: 387-392. Link: https://goo.gl/hsZYDk

16. Franz M, Horl WH (1999) Common errors in diagnosis and management of urinary tract infection II: clinical management. Nephrol Dial Transplant 14: 2754-2762. Link: https://goo.gl/s6WHUz

17. Astal Z, Manama A, Sharif FA (2002) Antibiotic resistance of bacteria associated with community-acquired urinary tract infections in the southern area of the Gaza Strip. J Chemother 14: 259-264. Link: https://goo.gl/B4xrA4

18. Gordon KA, Jones RN (2003) Susceptibility patterns of orally administered antimicrobials among urinary tract infection pathogens from hospitalized patients in North America: comparison report to Europe and Latin America. Results from the SENTRY Antimicrobial Surveillance Program (2000). Diagn Microbiol Infect Dis 45: 295-301. Link: https://goo.gl/H1Z3v1

19. Rieger A, Horta JA (2003) Prevalência de patógenos bacterianos e perfil de sensibilidade aos antimicrobianos em uroculturas de amostras comunitárias Revista Brasileira de Análises Clínicas 35(supl): 37B

20. Rodrigues WF, Miguel CB, Nogueira AP, Ueira-Vieira $C$, Paulino Tde $P$, et al. (2016) Antibiotic resistance of bacteria involved in urinary infections in brazil: a cross-sectional and retrospective study. Int $\mathrm{J}$ Environ Res Public Health 13: 918. Link: https://goo.gl/pYdpLh

21. Barros E, Bittencourt H, Caramori ML, Machado A (2001) Antimicrobianos, Consulta rápida. Artmed, Porto Alegre.

22. Tavares W (2001) Manual de antibióticos e quimioterápicos. Artmed, São Paulo.

23. Perry CM, Jarvis B (2001) Linezolid: a review of its use in the management of serious gram-positive infections. Drugs 61: 525-551. Link: https://goo.gl/mNRyvq

24. Jones RN, Ballow CH, Biedenbach DJ (2001) Multi-laboratory assessment of the linezolid spectrum of activity using the Kirby-Bauer disk diffusion method Report of the Zyvox Antimicrobial Potency Study (ZAPS) in the United States. Diagn Microbiol Infect Dis 40: 59-66. Link: https://goo.gl/ViY1jY

Copyright: (c) 2017 de Siqueira e Silva MF, et al. This is an open-access article distributed under the terms of the Creative Commons Attribution License, which permits unrestricted use, distribution, and reproduction in any medium, provided the original author and source are credited. 